\title{
Environmentally Friendly Public Transport
}

\author{
M. Pejšová* \\ Faculty of Transportation Sciences-Czech Technical University in Prague, Konviktská 20, Prague \\ * Corresponding author: magda.pejsova@volny.cz
}

DOI: $10.2478 /$ trans-2014-0013

\begin{abstract}
The article "Environmentally Friendly Public Transport" deals with the impact of public transport on the environment by selected types of vehicles. Nowadays, many public transport operators face the necessity to renew their vehicle fleets and consequently decide how to acquire the best vehicle fleet composition with the lowest costs. They need to be competitive with other operators as well as with personal car transport; they need to provide sufficient comfort to passengers, be environmentally friendly, and last but not least, they need to have low operating costs. The renewal of the vehicle fleet traditionally strains an operator's budget. A good decision for a suitable alternative of operated vehicles, or a decision for a suitable mixture of operated vehicles, may have a crucial impact on operating costs and thus affect financial support from their founders. New alternatives are available thanks to the development of new technologies - traditional diesel buses meeting the emission standards of EURO 6, CNG buses, electric buses, trolleybuses, trams, buses with hydrogen fuel cells, etc. The presented work is trying to find the answer to the question of which alternative is ideal for operators from a short-term, medium-term and long-term perspective. The article presents a comparison of economic indicators of the operation of individual alternatives, their impact on the environment and their performance.
\end{abstract}

KEY WORDS: Public transport, environment, vehicle fleet, alternative fuel.

\section{ANALYSIS OF PUBLIC TRANSPORT SITUATION IN THE CZECH REPUBLIC}

City public transport in the Czech Republic consists of Prague underground, seven tram operations, thirteen trolleybus operations, and many bus operations. Some cities and towns use funiculars and water transport, but their importance is rather supplementary. Most of these services are run by 19 transport companies with a vehicle fleet of 702 trolleybuses, 1826 trams and 2888 buses which cover 326 million kilometres. These figures clearly show that public transport operation has a crucial impact on the environment in urban areas. Just last year these operators spent CZK 4330 million for the renewal of vehicle fleets, for which they acquired 30 trams, 21 trolleybuses, 131 diesel buses, and 9 CNG buses (SPD ČR, 2013). Despite this fact, the renewal of vehicle fleet is not fast enough and vehicle fleets are getting old. The combination of renewal of vehicle fleets and the necessity to reduce a negative impact on the environment results in efforts of the operators to cope with these challenges.

The market currently has available alternatives, such as hybrid vehicles, CNG vehicles, electric vehicles, for the needs of public transport. However, they differ in their emission and economic characteristics. 


\subsection{City CNG buses}

If omitting underground, trams and trolleybuses, which are naturally powered by electricity, we can put compressed natural gas to the first position among alternative fuels used by public transport in the Czech Republic. The operators usually claim that the main reasons for introducing $\mathrm{CNG}$ buses are the reduction of negative impact of buses on the environment, renewal of vehicle fleet, and reduction of costs on the operation of city public transport. Despite this fact, according to the Czech Gas Association, which monitors the trends in the use of $\mathrm{CNG}$ and regularly prepares statistical data from this field, there are so far only $2.5 \%$ CNG buses of all buses in the Czech Republic (or 512 CNG buses, including intercity buses). This figure should change after completing 8 projects in the area of Alternative transport, with the support of the Ministry of the Environment through the State Environmental Fund of the Czech Republic within its 57th call, support for the replacement of the oldest and the most environmentally harmful public transport buses by more environmentally friendly CNG buses (MŽP, 2013).

Most of the funds are allocated to the Moravskoslezský region, i.e. the area with the most problematic air conditions. Dopravní podnik Ostrava (City public transport Ostrava) will use the funds to replace up to one third of their diesel buses with CNG buses. In total, they plan to acquire up to $100 \mathrm{CNG}$ buses. A large project with the acquisition of $100 \mathrm{CNG}$ buses and the construction of a CNG filling station has been in progress in the city of Brno. The first 12 buses were acquired at the beginning of summer 2014 and the delivery of the remaining 88 buses is expected at the turn of 2014/2015. Based on the estimates of the Czech Gas Association, approx. $238 \mathrm{CNG}$ buses will be put into operation within a single year in the Czech Republic.

\subsection{Electromobility in city public transport in the Czech Republic}

Czech city public transport operators have also been trying other alternatives. The requirement to fill cities with locally emission-free vehicles can be reached through electric vehicles. Regarding city public transport, the development of electromobility in the Czech Republic is still in its testing phase, unless we consider trams and trolleybuses. The only public transport operator who uses electric buses on regular city public transport services is Dopravní podnik Ostrava. There are 4 vehicles in operation on one service in Ostrava. The type of vehicles is the so-called overnight charging vehicles, i.e. no need to charge while driving. Electric buses are used in operation in shifts between peak hours, the charging is provided during the noon break. The morning mileage is $85 \mathrm{veh} / \mathrm{km}$, the afternoon mileage is $100 \mathrm{veh} / \mathrm{km}$. The public transport company claims that the higher acquisition costs (CZK 8.5 million + CZK 2 million for the replacement of the traction battery halfway through the vehicle life span) are compensated with lower costs on operation, reduced emissions and lower noise by $8 \mathrm{~dB}$ in comparison with a diesel engine. The higher acquisition costs have a return rate of approx. 12 years. Further expansion of electric buses is prevented not only by economic factors, but also by smaller operating range per charging, which is approx. 150 to 180 kilometres. It is necessary to introduce a network of speed-charging stations, if possible at terminal stations, for common performances of $250-300 \mathrm{~km}$ in urban traffic (Dopravní podnik Ostrava, 2014).

\subsection{Hybrid and fuel cell buses in the Czech Republic}

The operators have even less experience with hybrid and fuel cell buses. The representative of fuel cell buses tested in city public transport operations in the Czech Republic is TriHyBus, a prototype produced for the demonstration of hydrogen technology, operated by ÚJV Řež 
within a project coordinated by ÚJV Řež and cofounded by $75 \%$ from EU sources. Being the prototype corresponds with the price which reached almost CZK 60 million for vehicle development and CZK 23 million for the hydrogen infrastructure (TriHyBus.cz, 2008). Therefore, massive expansion is not expected under the current conditions.

A mass produced 12-metre hybrid city bus Volvo 7700 with a parallel drivetrain was a hybrid bus tested in public transport services in Prague and in inter-city transport services in Chomutov. In comparison with a diesel bus the savings of fuel in operation ranged between 28 and $45 \%$. The measured values from Prague show an average consumption of $30.21 / 100 \mathrm{~km}$, which is an average saving of $28 \%$ in comparison to comparable diesel buses (Rác, 2012). The bus is very quiet thanks to switching off the engine when stopped and starting by an electric engine up to the speed of $20 \mathrm{~km} / \mathrm{h}$. The price for the hybrid is approx. one third higher than the traditional model. In comparison with diesel buses, the studies show a return rate from 5 to 10 years due to higher maintenance costs, depending on the savings on consumption costs.

\section{COMPARISON OF DRIVE CONCEPTS}

6 concepts were selected for an analysis and comparison. Three were based on combustion engines - Diesel, CNG, Diesel hybrid and three were non-emission ones - Hydrogen fuel cells, Trolleybus, Electric bus.

Although the basic decision making criteria of Czech operators for choosing new vehicles typically concern price and operating costs, it is necessary to take into account other properties of the concepts, otherwise we could make a statement that walking is the cheapest transport mode and we can cancel public transport.

Regarding the fact that comfort and design of vehicles can be provided at the same level for all vehicles, this article only deals with the aspects which are essential for the operation of city public transport and cannot be easily replaced.

They can be generally summarized into three areas:

- Financial aspects (acquisition and operating costs, and infrastructure costs);

- Performance aspects (Filling or charging time, mileage, dependence on the infrastructure, flexibility, etc.);

- Aspects of impacts on the environment (Well-to-wheel emissions, local emissions, noise).

\subsection{Financial aspects}

For the simplification, the materials for comparing financial aspects of individual drive concepts are based on the price for a city vehicle with the length of $12 \mathrm{~m}$ and include costs on energy consumption, acquisition costs, repair and maintenance costs, and other costs that are constant for all types of concepts. Figure 1 shows a comparison of all-life costs obtained from different information sources.

Although the calculated costs of individual sources differ greatly, the relationships between individual concepts are very similar. The graph shows that all-life costs on alternative fuels are much higher in comparison with diesel and CNG. The situation reflects the fact that diesel and CNG are well established products on the market with completed infrastructure. Trolleybuses have high acquisition and maintenance costs of the traction overhead line. The price for electric buses and fuel cell buses is influenced by the parts production, which does not allow the use of economies of scale. In addition, both concepts require completing the infrastructure/hydrogen production. 
It is expected that the development of technologies and change to mass production will reduce the costs on electric buses and fuel cell buses, while the trend for diesel and CNG drives will be reversed due to the increase in prices of fossil fuels.

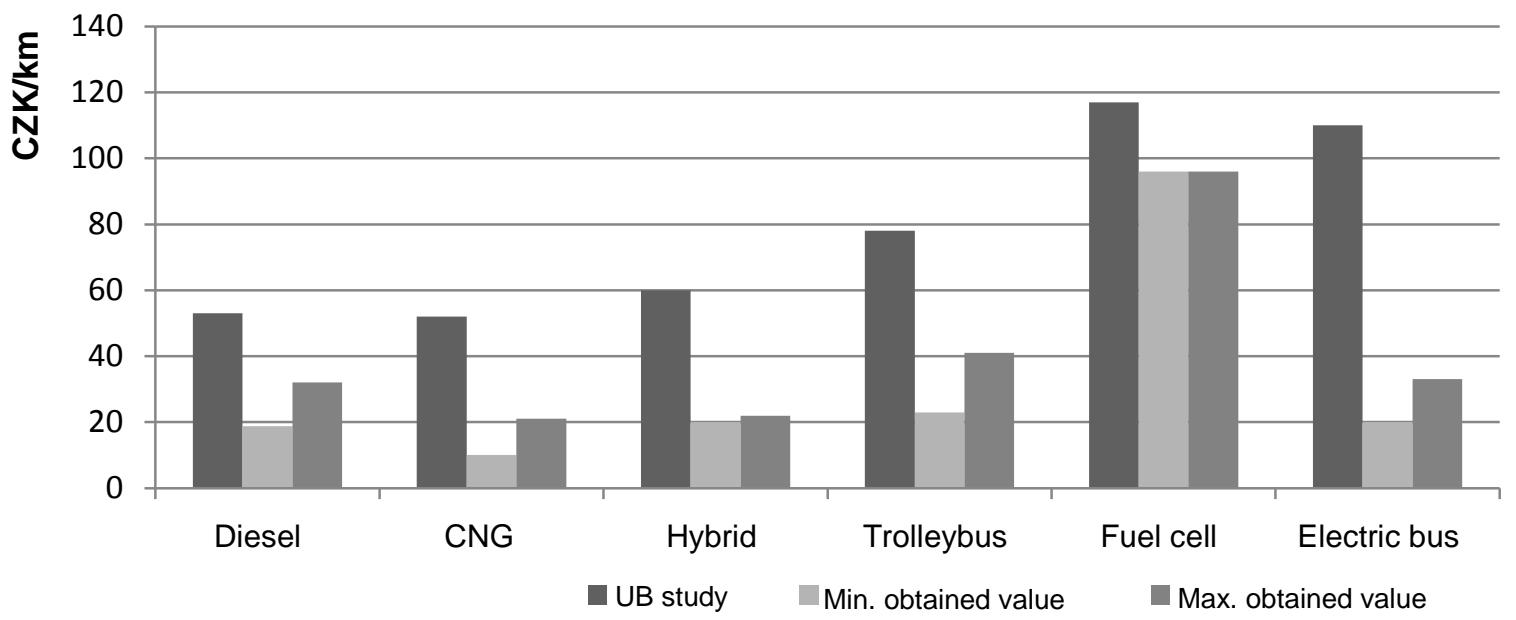

Figure 1: Total costs translated to $\mathbf{k m}$.

(Source: Slavík, 2013)

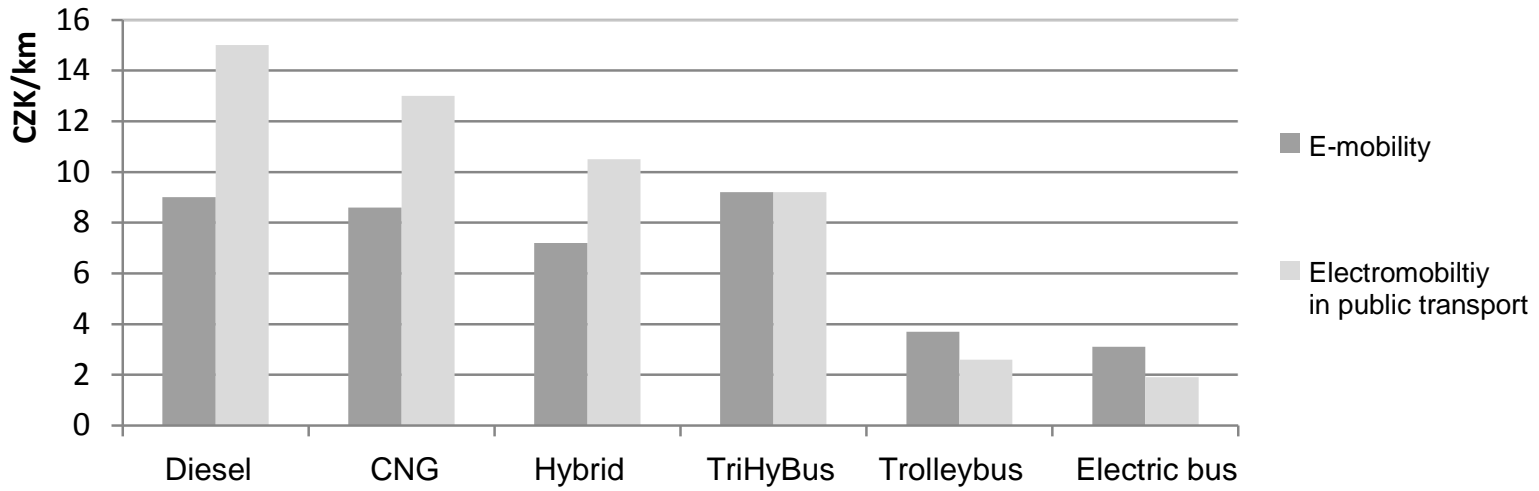

Figure 2: Consumption costs.

(Source: Slavík, 2013; Černý \& Pech, 2013)

Regarding the total costs, it is interesting to compare consumption costs where diesel and $\mathrm{CNG}$ are among the most expensive. Diesel is particularly influenced by the price of fuel while CNG is by consumption (Figure 2).

\subsection{Performance aspects}

Regarding the performance, city public transport operators are interested in key properties, such as fuel consumption, reliability, mileage per full tank of fuel, functional infrastructure, frequency and time of fuel filling, and last, but not least the property related to the impact of bus operation on the environment - operating range without locally produced emissions.

Regarding the first two mentioned properties, i.e. fuel consumption and reliability, they are directly reflected in the costs, thus this article does not pay more attention to them. The article just states that the more conventional technology, the higher reliability of the technology. However, if we considered this risk as a key factor, nothing new would ever be developed and no progress would exist. 
The other mentioned properties are balanced in different drive concepts. Some concepts show better properties in large mileage without producing emissions, others in absolute mileage.

Diesel and CNG buses have an operating range for a single full tank of fuel of longer than $300 \mathrm{~km}$, require a short time for fuel filling and can use a functional extensive network of filling stations at the European level. In the Czech Republic, the CNG infrastructure lags behind the European average. However, neither of the concepts can work in the mode with zero emissions.

Hybrid buses have the same properties as the convention ones, and what is more, in short sections they are able to use purely electric drive with zero emissions and lower noise, which increases their use particularly in city centres.

Hydrogen fuel cell buses are actually at the highest level in terms of performance, since they meet everything the conventional buses do with the added value of continuous operation with zero local emissions for a longer distance. However, the problematic factor is the insufficient infrastructure and the ever developing technology is still at the testing stage.

Trolleybuses offer a similar performance as conventional buses, with zero local emissions and without the need of fuel filling. However, the operating range is limited to the traction overhead line. The exception is hybrid trolleybuses which are used in some cities to increase flexibility.

Electric buses have a short mileage range and require a longer time for charging. Their advantage is the operation without emissions. Regarding charging, there are two options, either speed charging during the operation, which requires construction of charging stations along the route and causes complications in case of rerouting of services, or the so-called overnight charging, which is then demanding in terms of time.

\subsection{Aspects of traffic impact on the environment}

\subsubsection{Greenhouse gas emissions}

The latest study dealing with a comparison of traffic impact of different drive buses on the environment is "Urban Buses: Alternative Powertrains for Europe". The study concerns the impacts on the environment in the form of "well-to-wheel", so that the impact at the place of operation "tank-to-wheel" was mapped as well as the emissions concerning the production and delivery of energy to vehicle "well-to-tank".

The study shows a production of greenhouse gases of individual drive concepts in comparison with the production of emissions of a diesel engine. To be more illustrative, the study shows the averages of measured values, not the specific values, which vary for each region in terms of different structure of electric energy production, sources of fossil fuels, etc. (FCH-JU, 2012).



Figure 3: Emission structure.

(Source: FCH-JU, 2012) 
The collected information show that buses with electric drive produce the lowest amount of greenhouse gas emissions. In this respect, diesel and $\mathrm{CNG}$ buses are the most problematic. What is rather surprising is the production of local greenhouse gas emissions of CNG buses, which are generally considered more environmentally friendly than diesel buses (Figure 3).

Comparisons of diesel buses and CNG buses were dealt with by more studies, namely "Performance and emissions evaluation of compressed natural gas and clean diesel buses at New York City's Metropolitan Transit" (2002), "Comparative Costs of 2010 Heavy-Duty Diesel and Natural Gas Technologies" (California) and "Clean Diesel versus CNG Buses" (Manchester). Their results cannot be compared between each other since they were performed with completely different input conditions. The studies show that emissions from two of the most serious pollutants, PM and NOx, can be significantly lower with CNG engines - generally $70 \%$, or $30 \%$ - in comparison with traditional older diesel buses. However, no up-to-date objective comparison of emission production of new diesel and CNG buses is available. Whether CNG drive is more environmentally friendly than diesel drive or not, CNG technologies have a remarkable ability to meet the strictest emission standards required in advanced countries, while helping to improve the air quality in many urban areas around the developing world. Therefore, they represent an interesting alternative to diesel engines, although they are unable to work in an emission-free mode.

\subsubsection{Noise}

Apart from exhaust gas emissions, transport affects the environment by noise. A comparison of individual selected drive concepts is shown in Figure 4 (FCH-JU, 2012).

It is not surprising that the systems with electric drive are the least noisy, although buses with hydrogen cells produce equally low level of noise. The difference of 17 or $8 \mathrm{~dB}$ may seem negligible, but it is necessary to realize that the noise of $63 \mathrm{~dB}$ corresponds with a common conversation, while $80 \mathrm{~dB}$ corresponds with very loud music from loudspeakers. In addition, expert studies claim that hearing can be damaged by longterm exposure to noise slightly above the level of $70 \mathrm{~dB}$.

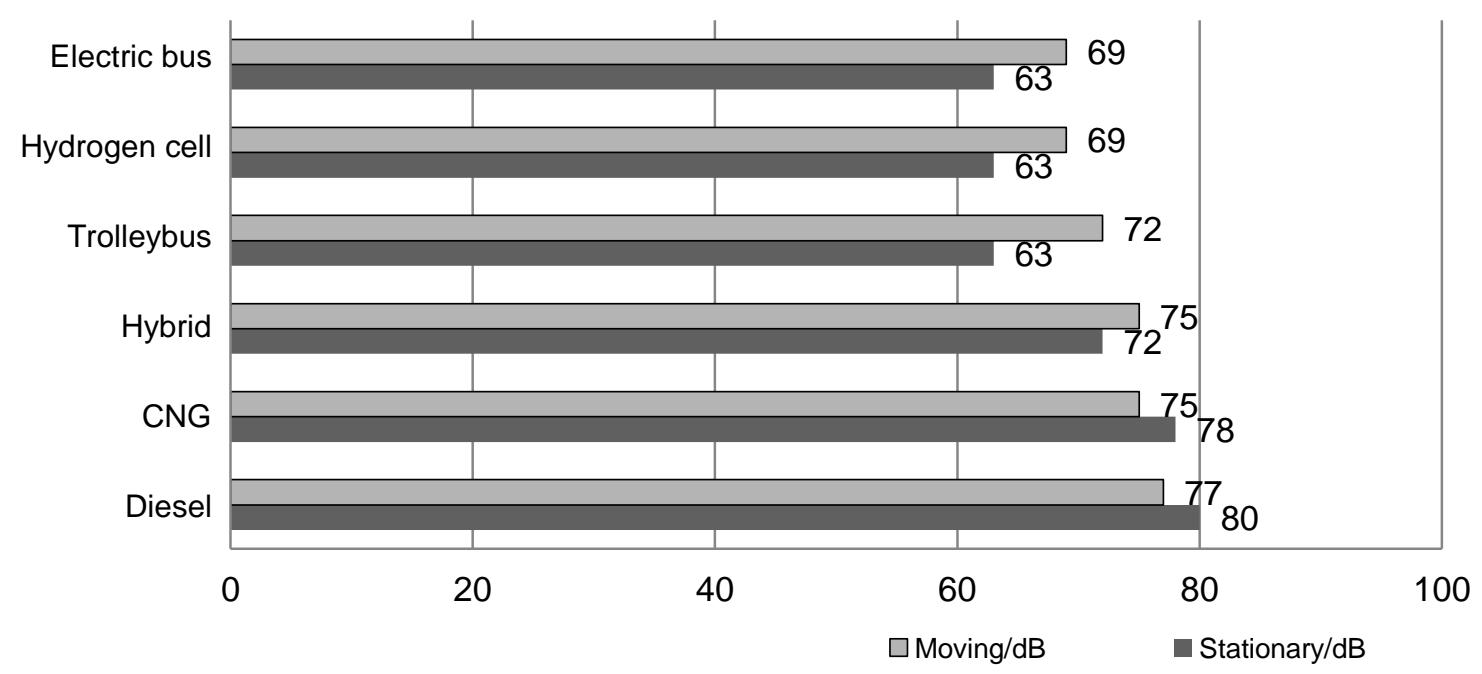

Figure 4: Noise.

(Source: FCH-JU, 2012) 


\section{RESULTS AND RECOMMENDATIONS}

The following summary may become handy when making the decision which direction to take and which drive concepts to accept for the renewal of vehicle fleet. According to the obtained results, all evaluated drive concepts were assigned with numbers from 1 to 3 , with 1 standing for the best evaluation. Table 1 shows the ranking of each concept.

Table 1: Final evaluation.

\begin{tabular}{|c|c|c|c|c|c|c|c|}
\hline & & Diesel & CNG & Hybrid & Trolleybus & $\begin{array}{c}\text { Hydrogen } \\
\text { cells }\end{array}$ & Electric bus \\
\hline \multirow{3}{*}{$\begin{array}{l}\text { Financial } \\
\text { aspects }\end{array}$} & Acquisition costs and funding & 1 & 1 & 2 & 3 & 3 & 2 \\
\hline & Operating costs & 3 & 2 & 2 & 3 & 1 & 1 \\
\hline & Infrastructure costs & 1 & 1 & 1 & 2 & 3 & 2 \\
\hline \multicolumn{2}{|c|}{ TOTAL FOR FA } & 5 & 4 & 5 & 8 & 7 & 5 \\
\hline \multirow{3}{*}{$\begin{array}{l}\text { Performance } \\
\text { aspects }\end{array}$} & Time of charging/ fuel filling & 2 & 2 & 2 & 1 & 2 & 3 \\
\hline & $\begin{array}{l}\text { Mileage range without } \\
\text { emissions }\end{array}$ & 3 & 3 & 2 & 1 & 1 & 1 \\
\hline & Flexibility/ mileage range & 1 & 1 & 1 & 3 & 1 & 2 \\
\hline \multicolumn{2}{|c|}{ TOTAL FOR PA } & 6 & 6 & 5 & 5 & 4 & 6 \\
\hline \multirow{3}{*}{$\begin{array}{l}\text { Aspects of } \\
\text { impacts on the } \\
\text { environment }\end{array}$} & Emissions well-to-wheel & 3 & 3 & 2 & 1 & 1 & 1 \\
\hline & Local emissions & 3 & 3 & 2 & 1 & 1 & 1 \\
\hline & Noise & 3 & 3 & 2 & 2 & 1 & 1 \\
\hline \multicolumn{2}{|c|}{ TOTAL FOR AIoE } & 9 & 9 & 6 & 4 & 3 & 3 \\
\hline \multicolumn{2}{|l|}{ TOTAL } & 20 & 19 & 16 & 17 & 14 & 14 \\
\hline
\end{tabular}

The obtained results show that any significant reduction of the impact of city public transport on the environment can only be achieved by applying alternative drive systems in practice. Nowadays, in the era of available and developing alternative drive systems, only hydrogen cell buses, trolleybuses and electric buses can play a key role in reducing the production of greenhouse gases and dealing with the issue of air pollution in cities. Therefore, the development and increasing of market share for electric buses and hydrogen cell buses need to be supported as much as possible in the cities with the previously built infrastructure.

Diesel hybrid buses, whose overall evaluation is better than that of CNG buses, can help to reduce local emissions up to $20 \%$ and overcome the time period before the concepts with zero local emissions get cheaper.

The cheapest alternatives, diesel and CNG drives, are unable to compete with the others in terms of the impact on the environment. However, their strong position in the market, provided infrastructure, flexibility and variability will be a tough nut to crack for the new technologies.

Cities are usually the majority owners of transport companies running city public transport in the Czech Republic. Politicians, who make the final decision regarding the investments in vehicle fleets as the representatives of the owner, usually forget about their pre-election promises on the improvement of the environment and decide to buy more vehicles for less money. Therefore, politicians and transport operators should cooperate and synchronize their efforts to support renewal of vehicle fleets with vehicles with zero emissions. Continuous and regular purchases of buses with new technologies may help to strengthen their position in the market, increase savings from economies of scale, and increase the effort of producers to develop and offer new products. 
We need to bear in mind that the life span of buses is longer than 12 years and the buses acquired this year will still be in operation in 2026. To reach the results in improving the environment as soon as possible we should not hesitate to introduce new concepts now.

\section{REFERENCES}

Černý, J., Pech, L., 2013. Elektromobilita v městské hromadné přepravě osob. Elektrobusy hromadné dopravní prostředky pro 21. století. Busportal [online]. [cited 2014-07-20]. Retrieved from: http://www.busportal.cz/bpextend/23_Cerny_Evmhpo-revize-I.pdf (in Czech)

Dopravní podnik Ostrava, 2014 [online]. (C) Dopravní podnik Ostrava a.s. [cited 2014-10-31]. Retrieved from: http://www.dpo.cz (in Czech)

FCH-JU, 2012. Urban buses: alternative powertrains for Europe [online]. FCH-JU (Fuel Cells and Hydrogen Joint Undertaking) [cited 2014-07-20]. Retrieved from: http://www.fch-ju.eu/sites/default/files/20121029\%20Urban\%20buses, $\% 20$ alternative $\%$ 20powertrains $\% 20$ for\%20Europe\%20-\%20Final\%20report_0.pdf

MŽP, 2013. Financování ochrany životního prostředí [online]. C) 2008-2014 Ministerstvo životního prostředí [cited 2014-10-31]. Retrieved from: http://www.mzp.cz/cz/financovani_ochrana_zivotni_prostredi (in Czech)

Pejšová, M. Městská hromadná doprava, která neškodí [Environmentally Friendly Public Transport]. In Jandová, V., Mikulová, I., Ličbinský, R. (eds.). VI Czech and Slovak Conference „Transport, Health and the Environment“, Brno (Czech Republic), November 10-11, 2014. Brno: Transport Research Centre, pp. 125-132. ISBN 978-80-86502-85-4. (in Czech)

Rác, J., 2012. Dopravní podnik měst Chomutova a Jirkova testoval hybridní autobus VOLVO 7700. Busportal [online]. [cit. 2014-07-20]. Retrieved from: http://www.busportal.cz/modules.php? name=article\&sid=9939 (in Czech)

Slavík, J., 2013. Elektrobusy v ČR a ve světě: studie „E-mobilita v MHD“. Proelektrotechniky.cz [online]. (C) 2012 Ing. Jakub Slavík, MBA - Consulting Services [cited 2014-07-20]. Retrieved from: http:/www.proelektrotechniky.cz/elektromobilita/42.php (in Czech)

SPD ČR, 2013. Výroční zpráva SDP ČR za rok 2013. Praha (Czech Republic): SDP ČR. (in Czech)

TriHyBus.cz, 2008. TriHyBus - Vodíkový autobus s palivovými články [online]. C Copyright 2008 TriHyBus.cz [cited 2014-10-31]. Retrieved from: http://www.h2bus.cz/ (in Czech)

NOTICE: The article was taken over from the proceedings of VI Czech and Slovak Conference "Transport, Health and the Environment" held on 10 - 11 November 2014 in Brno (Czech Republic), upon the decision of the proceedings publisher Transport Research Centre and with the consent of the author of the article.

With the consent of the author, the article was adapted on the basis of editing instructions of Transactions on Transport Sciences journal and translated into English language. 